\begin{tabular}{|c|c|c|}
\hline & Int.J.Curr.Microbiol.App.Sci (2021) 10(12): $492-508$ & \\
\hline & $\begin{array}{l}\text { International Journal of Current Microbiology and Applied Sciences } \\
\text { ISSN: 2319-7706 Volume } 10 \text { Number } \mathbf{1 2} \text { (2021) } \\
\text { Journal homepage: } \underline{\text { http://www.ijcmas.com }}\end{array}$ & $\$ 0$ \\
\hline $\begin{array}{l}\text { EXCELLENT } \\
\text { PUBLISHERS }\end{array}$ & & \\
\hline
\end{tabular}

\title{
Antibiogram and Bacteriological Analysis of Biofilm Producing Isolates in Bore Hole Water from Hospitals facilities in Port Harcourt Rivers State
}

\author{
*Williams, Janet Olufunmilayo, Douglas, Salome Ibietela and \\ Onyedibia, Golden Chukwuma
}

\author{
Department of Microbiology, Faculty of Science, Rivers State University, PMB 5080, \\ Nkpolu-Oroworukwo Port Harcourt, Rivers State, Nigeria
}

*Corresponding author

\section{A B S T R A C T}

\section{Keywords}

Antibiotics,

biocides, heavy

metals, World

Health Organization

Article Info

Received:

05 November 2021

Accepted:

05 December 2021

Available Online:

10 December 2021
The study was conducted at three (3) hospitals; University of Port Harcourt Teaching Hospital (UPTH), Meridian Hospital D / line branch (MRD1) and Meridian Hospital Ikoku branch, all located in Port Harcourt, Rivers State. Sample collection was for three (3) months, analysis was carried out daily for six (6) months. A total of Forty-five (45) water samples were collected for a period of three (3) months from the three (3) hospitals. The samples were labelled properly, according to date and time of collection. The collected samples were subjected to standard microbiological procedures which included standard plate counts, identification, biofilm screening, sensitivity testing using Kirby-Bauer disk diffusion method, Phenotypic screening of extended spectrum beta lactamase and molecular characterization of the isolates. The physicochemical and bacteriological quality of the water samples were analysed using standard methods. The results of the bacterial population of water samples from the hospitals showed that the total heterotrophic bacterial counts ranged from 0.7 to $1.1 \times 10^{4} \mathrm{cfu} / \mathrm{ml}$ while total coliform and faecal coliform counts ranged from 0.3 to $0.5 \times 10^{2} \mathrm{cfu} / \mathrm{ml}$ and 0.1 to $0.2 \times 10^{2}$ $\mathrm{cfu} / \mathrm{ml}$, respectively. There was a significant difference $(\mathrm{p} \leq 0.05)$ in the total heterotrophic bacterial, total coliform and faecal coliform counts between the hospitals sampled. A total of nineteen (19) bacterial isolates were isolated from water samples and $13(68.4 \%)$ isolates were identified as biofilm producers. The biofilm bacteria identified were $46.1 \%$ Staphylococcus, $15.4 \%$ E. coli, $23.1 \%$ Pseudomonas and $15.4 \%$ Proteus species. Biofilm forming ability of bacteria is considered a virulent factor and it is implicated to being a possible cause of increased resistance to most antibiotics. Varying susceptibility patterns was observed among biofilm isolates. Biofilm bacteria were resistant to several groups of antibiotics. Ofloxacin, Gentamycin, Imipenem and Nitrofurantoin can be used as drugs of interest for biofilm producing bacteria associated with bore hole water from hospitals studied. CTX-M and TET A gene were identified in Pseudomonas aeruginosa and Proteus mirabilis biofilm bacteria in this study and could be possible factors that confer resistance to antibiotics. The presence of icaD and papC gene in Pseudomonas aeruginosa and Proteus mirabilis have been found from genomic studies to be possible factors that confer biofilm producing ability. This study highlighted the presence of biofilm producing bacteria in bore hole water and their resistance to antibiotics. Therefore, there is need for improvement in water treatment practices as well as therapeutic guidance for confirmed infections related to consumption of water containing bacteria with biofilm producing ability. 


\section{Introduction}

Biofilm is a heterogeneous bacterial community that is protected against desiccation, antibiotics, biocides, heavy metals, and ultraviolet radiation by a slime matrix (21). Microorganisms are thought to be responsible for more than $65 \%$ of bacterial infection when they form biofilms (12).

Several water-related disease outbreaks have been attributed to deficiencies in water distribution systems. Hospital water sources can be effective sources of infection. According to the World Health Organization, drinking water should be free from anything that could endanger human health (52). Water is usually treated before distribution to users and their level of treatment before leaving the treatment facility should be within the limits set by World Health Organization. Unfortunately, during use, the quality of water may vary from the treatment time. In addition, disinfection greatly reduces microbial load but does not eliminate them completely. This allows the surviving bacteria to grow in desirable conditions(20). A decrease in water quality can lead to subsequent growth of highly pathogenic bacteria, due to systemic faults such as cross-linking, broken water pipes and contamination during pipe installation (9). In addition, these bacterial cells can attach to and build biofilms in pipeline areas where cells can be released into the fluid (9). Most bacteria found in drinking water systems exist in biofilms, rather than in free state (9). A high heterotrophic plate count may indicate biofilm formation in the water or piping system as reported by General Laboratory Technology (25). The growth of biofilms causes alteration in the turbidity, taste, colour, and odour of water (10). The problem arising from the use of such water can be immediate or not; but consideration of water quality becomes of interest when emerging concerns arise in their use (2).
Biofilms are naturally heterogeneous. When bacteria are in sessile form, they respond and behave differently than when they are in planktonic form (7). One of the most significant of these is the rise in antibiotic resistance (33). The velocity of diffusion of an antibacterial agent aimed at a biofilm is slowed by the extracellular polymeric matrix found in biofilm communities (55). This is accomplished by the extracellular polymeric structure interacting chemically with antibacterial agents or by slowing the rate of diffusion (51). Microorganisms develop biofilm to maintain their survival (27).

The presence of biofilm producing bacteria in borehole water presents need for public health intervention. As we know, water is used throughout food process and is used directly by humans, so it is necessary to determine the water quality. Some recurring human-related water infections have been reported, with biofilm-producing bacteria suspected as being the underlying cause (47). As a result, the requirement to isolate and identify bacteria in borehole water, as well as examine the biofilm development potential of bacterial isolates in distinct hospital water samples, emerges.

Planktonic cells are eliminated by antibiotic treatment while sessile forms are resistant and continue to grow inside biofilm (14). A surge in antimicrobial-resistant forms of bacteria has been noticed in recent years and among the bacteria discovered to exhibit antibiotic resistance are those that generate biofilms (47).

This is due to increasing antibiotic tolerance (44). Current antibiotic treatment guidelines do not reflect changes in the environmental dynamics of various bacteria (24). The belief that they would eradicate the same sort of bacteria regardless of where they are present is a primary driver of antibiotic resistance (29). Antimicrobials can enhance the production of 
biofilm in a number of bacterial strains when delivered at a low level of inhibition (46). This is especially important since underlying cells within the biofilm may be subjected to low levels of antibiotic resistance.

Antibiotics can increase biofilm growth rather than restrict it (31). Given the relevance of the aforementioned concerns to public health, it is critical to identify the bacterial isolates. collected from hospital bore hole water, evaluate the bacterial isolates potential to produce biofilms and determine drug delivery techniques for reducing water-related bacterial biofilm infections.

\section{Materials and Methods}

\section{Study Area}

The study was conducted at three (3) hospitals; University of Port Harcourt Teaching Hospital (UPTH), Meridian Hospital D/line branch (MRD1) and Meridian Hospital Ikoku branch (MRD2), all located in Port Harcourt Metropolis, Rivers State.

\section{Collection of Samples}

A total of 45 water samples were collected for a period of three (3) months from the three (3) hospitals. The samples were labelled properly, according to date and time of collection. The water samples were collected using sterile specimen containers in ice chest and transported aseptically to the Department of Microbiology Laboratory, Rivers State University, Port Harcourt, Nigeria for bacteriological analysis.

\section{Preparation of Samples}

Samples were prepared in accordance with the guidelines of the Clinical Laboratory Standard Institute (11). The media for bacterial culture were Nutrient, MacConkey, Mannitol Salt and
Cetrimide Agar as well as Eosin Methylene Blue (EMB) were prepared according to Manufacturer's instructions.

\section{Bacteriological analysis}

\section{Bacterial enumeration}

Tenfold serial dilution was done on the water samples, in which $1 \mathrm{ml}$ of water was transferred to $9 \mathrm{ml}$ of normal saline and further dilutions were done up to $10^{6}$. Aliquot $(0.1 \mathrm{ml})$ of appropriate dilutions $\left(10^{0}, 10^{1}\right.$ and $\left.10^{2}\right)$ were spread plated in duplicates on Nutrient, MacConkey, Cetrimide and Mannitol Salt Agar as well as Eosin Methylene Blueusing the spread plate technique. The plates were incubated at $37^{\circ} \mathrm{C}$ for 16 to 24 hours. The colonies on the plates was counted and described morphologically. The colonies formed on EMB and MacConkey were used for the enumeration of the population of coliforms. Colonies formed on Nutrient Agar was used to estimate the total heterotrophic count (THB). Cetrimide Agar and Mannitol Salt Agar selectively supported the growth of desired bacteria.

\section{Bacterial isolation}

Isolation of bacteria was done using standard microbiological procedures. The test samples were cultured on the different media. Emerging cultures were examined for distinct colonies, from which inocula were subcultured onto sterile solid plates for growth. Uniformity of colonies marked purity and the pure cultures were subjected to characterization and identification. Characterization was based on colony morphology, microscopic properties and some unique biochemical tests were carried out to confirm isolates(51). Identification was first based on matching properties with existing taxa in standard manuals including the manual for identification of medical bacteria (13) and the 
Bergy's manual of Determinative bacteriology (8). Further identification was done through Molecular technique (PCR) to confirm the identities of the isolates to species level.

\section{Biofilm screening}

Bacterial isolates obtained from the samples were tested for their biofilm producing capacity using the Congo red test method (22).

\section{Biofilm Screening by Congo Red Agar Method}

The method described by (22) is a simple qualitative way to detect biofilm production among bacterial isolates using Congo Red Agar (CRA) Medium. This method was used to determine the bacterial isolates that produce biofilms. In this regard, the test organisms were inoculated on Congo Red Agar and incubated at $37^{\circ} \mathrm{C}$ for 24 hours. The formation of black crystalline colonies marks a positive test for biofilm production.

\section{Antibiotic Sensitivity Testing}

\section{Agar disk diffusion method}

A sterile swab stick was immersed into the tube containing the bacterial suspension and the turbidity was equivalent to $0.5 \mathrm{~m}$ McFarland Turbidity Standard and the swab was used to swab the surface of the petri dish evenly which contained already prepared Mueller Hinton agar in three dimensions and rotating the plates to about $60^{\circ}$ to ensure even distribution of the organism. The agar was allowed to dry for about 3-5minutes. With Sterile forceps, the impregnated antimicrobial discs were placed evenly on the surface of the inoculated plate and the disc was placed $15 \mathrm{~mm}$ away from the edge of the plate. The head of the forceps was used to press down each disc slightly to make contact with the agar. After applying the discs, the plates were incubated in an inverted position aerobically at $35^{\circ} \mathrm{C}$ for $16-18 \mathrm{~h}$. After incubation, the test plates were examined to determine the zones of inhibition. The diameter of each zone of inhibition was measured in mm using a ruler and recorded for reference purpose (11).

\section{Extended Spectrum Beta-lactamase (ESBL) production}

Isolates were screened phenotypically to determine the presence or absence of extended spectrum beta- lactamases enzyme. The ceftazidime resistant strains were screened for ESBL production by using disc diffusion test. The increase in the zone of the diameter of $\geq$ $5-\mathrm{mm}$ between ceftazidime $(30 \mu \mathrm{g})$ and ceftazidime-clavulanate $\quad(30 / 10 \mu \mathrm{g}) \quad$ was considered ESBL positive (56).

\section{Metallo Beta-lactamase (MBL) production}

Isolates were screened phenotypically, to determine the presence or absence of Metallo beta- lactamases enzyme. Imipenem-resistant strains were tested for MBL production by combined disc diffusion assay using two imipenem discs, one with added $10 \mu \mathrm{l}$ of $0.5 \mathrm{M}$ EDTA. The increased zone of inhibition of $>7 \mathrm{~mm}$ around the mipenem-EDTA disc in comparison to zone size of imipenem disc alone was confirmed positive for $\mathrm{MBL}$ production (56).

\section{Results and Discussion}

\section{Bacterial Population}

The results of the bacterial population of water samples from the hospitals showed that the total heterotrophic bacterial counts ranged from 0.7 to $1.1 \times 10^{4} \mathrm{cfu} / \mathrm{ml}$ while Total coliform and faecal coliform counts ranged from 0.3 to $0.5 \times 10^{2} \mathrm{cfu} / \mathrm{ml}$ and 0.1 to $0.2 \times 10^{2}$ $\mathrm{cfu} / \mathrm{ml}$, respectivelyand this is a strong evidence of faecal contamination. The study 
carried out by (3) also recorded higher faecal coliform counts of about 0.0 to $2.3 \times 10^{2} \mathrm{cfu} / \mathrm{ml}$ in a similar study of drinking water assessment. There was a significant difference $(p \leq 0.05)$ in the total heterotrophic bacterial, total coliform and faecal coliform counts between the hospitals sampled.Significant difference observed in the bacterial population of water samples can be attributed to the difference in environmental conditions across hospitals studied, the state of the pipping materials, as some pipes were broken which presents a route for microbial contamination (19). Meridian Hospital, Ikoku (MRD2) had higher microbial load compared to others. This can be attributed to the proximity between the borehole and the septic tank. The elevated levels of bacteria count according to (5) indicates more likelihood of the dangers which the bacterial isolates pose to its hosts body with respect to consumers. The bacterial counts obtained do not satisfy the permissible count of total heterotrophic bacterial counts in portable water and this gives a clear indication of bacterial regrowth and post-treatment failure/contamination (19).

\section{Physicochemical Quality of Water Samples}

$\mathrm{pH}$ is one of the most important water quality parameters. Measurement of $\mathrm{pH}$ relates to the acidity or alkalinity of the water. Water is considered to be acidic if the $\mathrm{pH}$ is below 7.0. Meanwhile, it is alkaline if the $\mathrm{pH}$ is higher than 7.0. Acidic water can lead to corrosion of metal pipes and plumping system. Meanwhile, alkaline water shows disinfection in water. The normal drinking water $\mathrm{pH}$ range stipulated by World health organization (54) and National Drinking Water Quality Standard (37) guidelines is between 6.5 and 9 (Table 1). The $\mathrm{pH}$ of water samples obtained from different hospital boreholes ranged from 5.15 to 5.73 as recorded in this study. The water samples obtained from the three (3) hospitals borehole were acidic. This can be caused by a number of natural phenomenon, one of them could be by mildly acidic rain, since rainfall lands as slightly acidic due to the carbon dioxide in the atmosphere, soil microbes that emit carbon dioxide and produces acids (39).

The presence of heavy metals in drinking water at concentrations higher than acceptable concentrations can cause detrimental impacts on humans. In this study, heavy metals such as iron, copper, zinc, lead and cadmium are compared with the safe limits set by World Health Organisation (53) and National drinking water quality standard (37). Concentration of lead in the water samples from the three (3) hospital locations was within the acceptable limit and this is possibly because of the plastic pipings used in the water distribution system and also the surrounding soil which may have a low amount of lead and would not interfere significantly in increasing lead concentration of water (28).

The iron concentration of water samples obtained from the three (3) hospital boreholes ranged from 0.12 to $0.20 \mathrm{mg} / 1$ as recorded in this study. Iron imparts a disagreeable metallic taste to water and the National Quality Drinking Water Standard (37) recommended a maximum of $0.3 \mathrm{mg} / \mathrm{l}$ concentration of iron for which this study deviates from. The presence of iron in ground water is a direct result of its natural existence in underground rock formations and precipitation water that infiltrates through these formations (45). Acidic water is more likely to leach heavy metals from the environment.

Electrical conductivity of the water ascertains the ability of water to conduct electricity. This is made possible by the presence of dissolved solids. These dissolved solids include calcium, magnesium and chloride. According to (54) and (37), the maximum allowable level of conductivity is $1000 \mu \mathrm{s} / \mathrm{cm}$. The result from 
this study reviewed that the measured conductivity of all bore hole water samples ranged from $14.1 \mu \mathrm{s} / \mathrm{cm}$ to $49.8 \mu \mathrm{s} / \mathrm{cm}$. The lowest and highest conductivity values correspond to MRD1 and MRD2, respectively. High mineral content results in high conductivity value. Moreover, according to (6) the differences among the values of electrical conductivity of tap water are not yet known. Conductivity does not have direct impact on human health. High conductivity will lower the aesthetic value of the water by giving a mineral taste to the water (30).

Turbidity is a key parameter to be considered in drinking water. Turbidity of water is caused by variety of contaminants in water. The standard recommended maximum turbidity limit as set by W.H.O and NDWQS for drinking water is 5 nephelometric turbidity units (NTU). This study recorded mean turbidity level of 0.10 nephelometric turbidity units (NTU) for water samples from UPTH, MRD1 and MRD2. The results obtained revealed that low turbidity values corresponded to low bacteriological counts and vice versa. This is also confirmed from the report of (40). Soil runoff is a major source of organisms in water, as water with high turbidity is suspected to have organisms in it. The water samples had turbidity levels below the standard recommended maximum turbidity level of $5 \mathrm{ntu}$ which is due to the filtration system adopted by the different hospitals to ensure efficient removal of undesirable solids and organisms from water.

The maximum recommended Total suspended solids (TSS) limit set by NDWQS is $25 \mathrm{mg} / \mathrm{L}$. Water samples showed very little Total suspended solids. This is because water systems had filtration systems attached, thus, removing suspended particles such as silt, clay and other inorganic particles. Total dissolved solids in water samples studied were within the maximum standard allowable total dissolved solid limit of $600 \mathrm{mg} / 1$ (53). The highest TDS values of $27.26 \mathrm{mg} / 1$ and the lowest TDS values of $7.03 \mathrm{mg} / \mathrm{l}$ corresponds to the water samples from MRD2 and MRD1, respectively. The TDS values were in accordance with the findings of (1).

Water samples were tested for hardness and this study revealed hardness range of $10 \mathrm{mg} / \mathrm{l}$ to $12 \mathrm{mg} / \mathrm{l}$ as presented in Table 4 . The results observed were within the World health organisation water hardness limit and the acceptable level of water hardness recorded in this study is because water samples had calcium, magnesium and copper within normal acceptable limits (52).

\section{Morphology and Biochemical Characteristics of Bacterial isolates}

Bacterial isolates were revealed on the basis of their colonial, morphological and biochemical characteristics. Nineteen (19) bacterial isolates belonging to the following genera were identified as Escherichia coli $21.1 \%$, Proteus $10.5 \%$, Pseudomonas 15.8\%, Salmonella $10.5 \%$, and Staphylococcus species $42.1 \%$.

The presence of these bacteria inbore hole water can be attributed to the fact that water treatment substantially reduces the number of microorganisms but does not sterilize it completely. This allows surviving bacteria to grow under favorable conditions (9).

\section{Antibiogram Assay of the Isolates}

The result of the antimicrobial pattern of the individual biofilm bacterial isolates; Escherichia coli, Proteus, Pseudomonas and Staphylococcus species are represented in Tables 2 to 5 . The result of the antimicrobial pattern of the individual Non-biofilm bacterial isolates; Escherichia coli, Salmonella and Staphylococcus species are represented in Tables 6 to 8 . The antibiogram profile of the 
isolates were graded as susceptible, intermediate and resistant.

\section{Bacterial isolates from samples and location}

A total of nineteen (19) bacteria were isolated from water samples obtained from the three (3) hospitals. The findings from this study showed the relative abundance of bacterial isolates identified from bore hole water of hospitals. The biofilm bacteria identified were Escherichia coli21.1\%, Proteus spp 10.5\%, Pseudomonas spp $15.8 \%$, Salmonella spp $10.5 \%$ and Staphylococcus spp $42.1 \%$. The detection of Escherichia coli among the isolates is strong evidence of faecal contamination (3). Meridian Hospital Ikoku had the predominant relative abundance $10(52.6 \%)$ followed by University of Port Harcourt Teaching Hospital 6(31.6\%) and Meridian Hospital D/Line had the least percentage occurrence $3(15.8 \%)$. The presence of Pseudomonas aeruginosa in the water samples from UPTH and MRD2 hospitals disagrees with the report of (35), where it was reported that Pseudomonas aeruginosa was not found in drinking water obtained from tap water, especially as the source of water are generally borehole. The observed variance in bacterial population observed in water samples obtained from bore hole across hospitals in this study can be due to the difference in environmental conditions across hospitals studied, the state of the pipping materials, as some pipes were broken which presents a route for microbial contamination.

\section{Biofilm Producing Bacterial Isolates}

A total of $13(68.4 \%)$ isolates were identified to be biofilm producers. Biofilm bacterial isolates were able to form biofilms due to the possession of adherent structures, such as flagella that aid motility to receptor sites (substratum). Escherichia coli 15.4, Proteus $15.4 \%$, Pseudomonas $23.1 \%$ and $46.1 \%$
Staphylococcus species were identified as biofilm producers having varying occurrence across hospital bore holes as shown in Fig 1 . Escherichia coli was present in UPTH and MRD2 at $7.7 \%$ and was absent in MRDI. Proteus sp was present in MRD1 and MRD2 at $7.7 \%$. Pseudomonas sp had a predominant relative abundance of $15.4 \%$ in MRD2 and least percentage relative abundance of $7.6 \%$ in UPTH. Staphylococcus sp were present in all hospital bore holes studied and result showed that MRD2 had the predominant relative abundance of $23.1 \%$ followed by UPTH $15.4 \%$ and least relative abundance of $7.6 \%$ in MRD1. The study revealed the presence of biofilm producing Staphylococcus sp in borehole water, which is in agreement with the findings of (34). Opportunistic pathogens such as Pseudomonas sp isolated from water and have been associated in biofilm production is in line with the work carried out by (43).

\section{Non-Biofilm Producing Bacteria Isolates from Bore Hole Water Samples and Location}

A total of 6(31.6\%) isolates were identified as Non-biofilm producers. Non-biofilm producers identified were Escherichia coli, Salmonella and Staphylococcus species at a percentage relative abundance of $33.3 \%$ each across hospitals. Escherichia coli was present in MRD1 and MRD2 at 16.6\%. Salmonella spp were present in UPTH and MRD2 at $16.6 \%$ and was not present in MRDI. Staphylococcus spp were present in UPTH and MRD2 at $16.6 \%$. Bacterial isolates such as Staphylococcus spp and Escherichia coli were observed to have biofilm and non- biofilm potentials. The difference in biofilm formation ability observed among bacterial isolates of same genera is due to strain types and genetic makeup of the isolates. Certain bacteria acquire this biofilm potential through transfer of genetic information among bacterial isolates in biofilm community. Irrespective of 
their inability to produce biofilm, they are infectious to humans (23).

Antibiotic Sensitivity pattern of biofilm producing bacteria isolated from various samples

The result of the antibiotic pattern of Escherichia colias shown in Table 2 indicates that greater number of Escherichia coli were susceptible to Ofloxacin, Nitrofurantoin and Imipenem (50\%). Susceptibility to Ofloxacin in this study concurs with the findings of(38). Escherichia coli showed complete resistance to Ceftazidime, Augmentin, Cefuroxime, Cefixime and Ciprofloxacin (100\%).

The result of the antibiotic pattern of Proteus spp as shown in Table 3 indicates that greater number of Proteus sp were susceptible to Nitrofurantoin and Ofloxacin $(100 \%)$. Proteus $s p$ showed complete resistance to Ceftazidime, Augmentin, Cefexime, Cefuroxime, Ciprofloxacin and (100\%).

The result of the antibiotic pattern of Pseudomonas spp as shown in Table 4 indicates that greater number of Pseudomonas sp were susceptible to Gentamycin (100\%) followed by Ofloxacin and Imipenem (66.6\%). Pseudomonas sp showed 100\% resistance to Ceftazidime, Augmentin, Cefuroxime and Cefexime.

The result of the antibiotic pattern of Staphylococcus spp as shown in Table 5 indicates that greater number of the Staphylococcus sp were susceptible to Ofloxacin (83.3\%), Gentamycin and Imipenem (66.7\%).

Staphylococcus sp showed complete resistance to Ceftazidime, Augmentin, Cefuroxime, Ceftriaxone and Cloxacillin (100\%). The observed susceptibility of Staphylococcus spp to Ofloxacin is in accordance with the report of (4). High sensitivity to gentamycin in this present study compares favourably with the reports of (36). The observed resistance to Cloxacillin in this study contradicts the findings of (36) which revealed that Cloxacillin was highly recommended in staphylococcal infection.

The main problem associated with biofilm forming bacteria is the low sensitivity of the bacteria to the antimicrobials used (41). The level of susceptibility of biofilm bacterial to Ofloxacin in this study can be attributed to its ability in killing biofilm cells and effectiveness on non-growing cells (50). The resistance to beta-lactam drugs is in line with the work of (42). Most organisms were resistant to Ceftazidime which is a cephalosporin group antibiotic. Ofloxacin, Gentamycin, Imipenem and Nitrofurantoin has been found from this study to be the drug of choice for Escherichia coli, Proteus, Staphylococcus and Pseudomonas species biofilm producers present in bore hole water.

The Multiple Antibiotic Resistance Index of biofilm forming bacteria isolated from bore hole water, revealed that Escherichia coli, Proteus, Pseudomonas and Staphylococcus species had multidrug resistance index of $100 \%$. multidrug resistance index values greater than 0.2 indicate a high risk where antibiotics are often used (16). This increase in resistance might result from poorly guided and frequent discard of antibiotic residues into natural sources, making the environment a storehouse of genetically resistant bacteria (15).

Antibiotics Sensitivity Pattern of NonBiofilm Producing Bacteria

Escherichia coli isolates as shown in Table 6 indicates that greater number of the Escherichia coli were susceptible to Ofloxacin, Ciprofloxacin and Gentamycin (100\%) This was followed by Cefexime, 
Nitrofurantoin, Augmentin and Imipenem $(50 \%)$. Gentamycin belongs to aminoglycosides group of antibiotics and the level of susceptibility observed is not surprising because it is known to work against gram negative bacteria such as $E$. coli, by binding to their ribosomes and inhibiting protein synthesis (48). Escherichia coli showed complete resistance to Ceftazidime (100\%).

The result of the antibiotic pattern of Salmonella spas presented in Table 7 indicated that a greater number of Salmonella spp were $100 \%$ susceptible to Ofloxacin, Gentamycin, Nitrofurantoin and Ciprofloxacin followed by Augmentin, Cefexime and Imipenem (50\%). Salmonella sp showed resistance to: Ceftazidime (100\%).

The result of the antibiotic pattern of Staphylococcus spp as shown in Table 8 indicates that greater number of Staphylococcus spp were susceptible to Gentamycin and Imipenem (100\%), Ofloxacin, Cefuroxime, Erythromycin, Ceftriaxone and Cloxacillin (50\%). Staphylococcus spp showed complete resistance to Ceftazidime and Augmentin $(100 \%)$

The Multiple antibiotic resistance Index of non-biofilm forming bacteria isolated from bore hole water samples, showed that Escherichia coli, Salmonella and Staphylococcus species had multidrug resistance index of $50 \%, 50 \%$ and $100 \%$, respectively.

Multiple antibiotic resistance index values in this study were greater than 0.2 , indicating a high risk (15).

\section{Distribution of biofilm formers, ESBL and MBL producers}

A total of $13(68.4 \%)$ bacterial isolates that tested positive to biofilm production were screened for extended spectrum betalactamase (ESBL) and metallo beta-lactamase (MBL). Out of which $8(42.1 \%)$ and $6(31.6 \%)$ were confirmed as ESBL and MBL producers. Proteus spp was detected as ESBL producers showing comparatively higher incidence of (100\%) followed by Staphylococcus spp (50\%), Pseudomonas spp (33.3\%) and Escherichia coli (25\%). Pseudomonas spp were identified to be the highest MBL producers i.e., $66.7 \%$ closely followed by Proteus spp (50\%). Other bacterial isolates such as Escherichia coli and Staphylococcus spp phenotypically expressed the presence of MBL enzyme at (25\%). The coexistence of biofilm along with both beta-lactamases producing strains was found to be $(26 \%)$. The biofilm matrix enhances the expression of resistant genes like beta-lactamases. This is in accordance with the findings of (17).The result of ESBL integration with MBL production and biofilm production revealed that high ESBL producers were biofilm bacteria and there was significant relationship between ESBL and biofilm formation ( $\chi^{2}=$ $2.73, \mathrm{P}$-value $=0.001$ )

This is contrary to the findings of (18). The significant association between ESBL and bacterial biofilm production observed in this study is because most biofilm producing bacteria isolated in this study were positive to extended spectrum beta-lactamases production. The link between MBL production and biofilm production was found to be statistically significant. $(\chi 2=2.01, \mathrm{P}$-value $=$ 0.002). 
Table.1 Antibiotics Sensitivity Pattern of Biofilm Producing Escherichia coli Isolated from Bore Hole Water

\begin{tabular}{|c|c|c|c|c|}
\hline Antibiotics & $\begin{array}{c}\text { Concentration } \\
(\boldsymbol{\mu g})\end{array}$ & $\begin{array}{c}\text { Resistant } \\
\mathbf{n}(\boldsymbol{\%})\end{array}$ & $\begin{array}{c}\text { Intermediate } \\
\mathbf{n}(\boldsymbol{\%})\end{array}$ & $\begin{array}{c}\text { Susceptible } \\
\mathbf{n}(\boldsymbol{\%})\end{array}$ \\
\hline OFL & 5 & $0(0.00)$ & $1(50.0)$ & $1(50.0)$ \\
\hline AUG & 30 & $2(100)$ & $0(0.00)$ & $0(0.00)$ \\
\hline CAZ & 30 & $2(100)$ & $0(0.00)$ & $0(0.00)$ \\
\hline CRX & 30 & $2(100)$ & $0(0.00)$ & $0(0.00)$ \\
\hline GEN & 10 & $0(0.00)$ & $2(100)$ & $0(0.00)$ \\
\hline NIT & 300 & $1(50.0)$ & $0(0.00)$ & $1(50.0)$ \\
\hline CPR & 5 & $2(100)$ & $0(0.00)$ & $0(0.00)$ \\
\hline CXM & 5 & $2(100)$ & $0(0.00)$ & $0(0.00)$ \\
\hline IMP & 30 & $0(0.00)$ & $1(50.0)$ & $1(50.0)$ \\
\hline
\end{tabular}

KEY: (AU) Augmentin, (CAZ) Ceftazidime, (CRX) Cefuroxime, (CTR) Ceftriaxone, (ERY) Erythromycin, (CXC) Cloxacillin, (NIT) Nitrofurantoin (CXM) Cefixime, (OFX) Ofloxacin, (GEN) Gentamycin, (CPX) Ciprofloxacin, (IMP) Imipenem

Table.2 Antibiotics Sensitivity Pattern of Biofilm Producing Proteus sp Isolated from Bore Hole Water

\begin{tabular}{|c|c|c|c|c|}
\hline Antibiotics & $\begin{array}{c}\text { Concentration } \\
(\boldsymbol{\mu g})\end{array}$ & $\begin{array}{c}\text { Resistant } \\
\mathbf{n}(\boldsymbol{\%})\end{array}$ & $\begin{array}{c}\text { Intermediate } \\
\mathbf{n}(\boldsymbol{\%})\end{array}$ & $\begin{array}{c}\text { Susceptible } \\
\mathbf{n}(\boldsymbol{\%})\end{array}$ \\
\hline OFL & 5 & $0(0.00)$ & $0(0.00)$ & $2(100)$ \\
\hline AUG & 30 & $2(100)$ & $0(0.00)$ & $0(0.00)$ \\
\hline CAZ & 30 & $2(100)$ & $0(0.00)$ & $0(0.00)$ \\
\hline CRX & 30 & $2(100)$ & $0(0.00)$ & $0(0.00)$ \\
\hline GEN & 10 & $1(50.0)$ & $0(0.0 .0)$ & $1(50.0)$ \\
\hline NIT & 300 & $0(0.00)$ & $0(00.0)$ & $2(100)$ \\
\hline CPR & 5 & $2(100)$ & $0(0.00)$ & $0(0.00)$ \\
\hline CXM & 5 & $2(100)$ & $0(0.00)$ & $0(0.00)$ \\
\hline IMP & 30 & $1(50.0)$ & $0(0.00)$ & $1(50.0)$ \\
\hline
\end{tabular}

KEY: (AU) Augmentin, (CAZ) Ceftazidime, (CRX) Cefuroxime, (CTR) Ceftriaxone, (ERY) Erythromycin, (CXC) Cloxacillin, (NIT) Nitrofurantoin (CXM) Cefixime, (OFX) Ofloxacin, (GEN) Gentamycin, (CPX) Ciprofloxacin, (IMP) Imipenem 
Table.3 Antibiotics Sensitivity Pattern of Biofilm Producing Pseudomonas sp Isolated from Bore Hole Water

\begin{tabular}{|c|c|c|c|c|}
\hline Antibiotics & $\begin{array}{c}\text { Concentration } \\
(\boldsymbol{\mu g})\end{array}$ & $\begin{array}{c}\text { Resistant } \\
\mathbf{n}(\boldsymbol{\%})\end{array}$ & $\begin{array}{c}\text { Intermediate } \\
\mathbf{n}(\boldsymbol{\%})\end{array}$ & $\begin{array}{c}\text { Susceptible } \\
\mathbf{n}(\boldsymbol{\%})\end{array}$ \\
\hline OFL & 5 & $0(0.00)$ & $1(33.3)$ & $2(66.6)$ \\
\hline AUG & 30 & $3(100)$ & $0(0.00)$ & $0(0.00)$ \\
\hline CAZ & 30 & $3(100)$ & $0(0.00)$ & $0(0.00)$ \\
\hline CRX & 30 & $3(100)$ & $0(0.00)$ & $0(0.00)$ \\
\hline GEN & 10 & $0(0.00)$ & $0(0.00)$ & $3(100)$ \\
\hline NIT & 300 & $1(33.3)$ & $1(33.3)$ & $1(33.3)$ \\
\hline CPR & 5 & $2(66.6)$ & $1(33.3)$ & $0(0.00)$ \\
\hline CXM & 5 & $3(100)$ & $0(0.00)$ & $0(0.00)$ \\
\hline IMP & 30 & $1(33.3)$ & $0(0.00)$ & $2(66.6)$ \\
\hline
\end{tabular}

KEY: (AU) Augmentin, (CAZ) Ceftazidime, (CRX) Cefuroxime, (CTR) Ceftriaxone, (ERY) Erythromycin, (CXC) Cloxacillin, (NIT) Nitrofurantoin (CXM) Cefixime, (OFX) Ofloxacin, (GEN) Gentamycin, (CPX) Ciprofloxacin, (IMP) Imipenem.

Table.4 Antibiotics Sensitivity Pattern of Biofilm Producing Staphylococcus sp Isolated from Bore Hole Water

\begin{tabular}{|c|c|c|c|c|}
\hline Antibiotics & $\begin{array}{c}\text { Concentration } \\
(\boldsymbol{\mu g})\end{array}$ & $\begin{array}{c}\text { Resistant } \\
\mathbf{n}(\boldsymbol{\%})\end{array}$ & $\begin{array}{c}\text { Intermediate } \\
\mathbf{n}(\boldsymbol{\%})\end{array}$ & $\begin{array}{c}\text { Susceptible } \\
\mathbf{n}(\boldsymbol{\%})\end{array}$ \\
\hline OFL & 5 & $1(16.7)$ & $0(0.00)$ & $5(83.3)$ \\
\hline AUG & 30 & $6(100)$ & $0(0.00)$ & $0(0.00)$ \\
\hline CAZ & 30 & $6(100)$ & $0(0.00)$ & $0(0.00)$ \\
\hline CRX & 30 & $6(100)$ & $0(0.00)$ & $0(0.00)$ \\
\hline GEN & 10 & $1(16.7)$ & $1(16.7)$ & $4(66.7)$ \\
\hline CTR & 30 & $6(100)$ & $0(0.00)$ & $0(0.00)$ \\
\hline ERY & 5 & $4(66.7)$ & $0(0.00)$ & $2(33.3)$ \\
\hline CXC & 5 & $6(100)$ & $0(0.00)$ & $0(0.00)$ \\
\hline IMP & 30 & $1(16.7)$ & $1(16.7)$ & $4(66.7)$ \\
\hline
\end{tabular}

KEY: (AU) Augmentin, (CAZ) Ceftazidime, (CRX) Cefuroxime, (CTR) Ceftriaxone, (ERY) Erythromycin, (CXC) Cloxacillin, (NIT) Nitrofurantoin (CXM) Cefixime, (OFX) Ofloxacin, (GEN) Gentamycin, (CPX) Ciprofloxacin, (IMP) Imipenem 
Table.5 Antibiotics Sensitivity Pattern of Non-Biofilm Producing Escherichia coli Isolated from Bore Hole Water

\begin{tabular}{|c|c|c|c|c|}
\hline Antibiotics & $\begin{array}{c}\text { Concentration } \\
(\boldsymbol{\mu g})\end{array}$ & $\begin{array}{c}\text { Resistant } \\
\mathbf{n}(\boldsymbol{\%})\end{array}$ & $\begin{array}{c}\text { Intermediate } \\
\mathbf{n}(\boldsymbol{\%})\end{array}$ & $\begin{array}{c}\text { Susceptible } \\
\mathbf{n}(\boldsymbol{\%})\end{array}$ \\
\hline OFL & 5 & $0(0.00)$ & $0(0.00)$ & $2(100)$ \\
\hline AUG & 30 & $1(50.0)$ & $0(0.00)$ & $1(50.0)$ \\
\hline CAZ & 30 & $2(100)$ & $0(0.00)$ & $0(0.00)$ \\
\hline CRX & 30 & $1(50.0)$ & $1(50.0)$ & $0(0.00)$ \\
\hline GEN & 10 & $0(0.00)$ & $0(0.00)$ & $2(100)$ \\
\hline NIT & 300 & $0(0.00)$ & $1(50.0)$ & $1(50.0)$ \\
\hline CPR & 5 & $0(0.00)$ & $0(0.00)$ & $2(100)$ \\
\hline CXM & 5 & $1(50.0)$ & $0(0.00)$ & $1(50.0)$ \\
\hline IMP & 30 & $0(0.00)$ & $1(50.0)$ & $1(50.0)$ \\
\hline
\end{tabular}

KEY: (AU) Augmentin, (CAZ) Ceftazidime, (CRX) Cefuroxime, (CTR) Ceftriaxone, (ERY) Erythromycin, (CXC) Cloxacillin, (NIT) Nitrofurantoin (CXM) Cefixime, (OFX) Ofloxacin, (GEN) Gentamycin, (CPX) Ciprofloxacin, (IMP) Imipenem

Table.6 Antibiotics Sensitivity Pattern of Non-Biofilm Producing Salmonella sp Isolated from Bore Hole Water

\begin{tabular}{|c|c|c|c|c|}
\hline Antibiotics & $\begin{array}{c}\text { Concentration } \\
(\boldsymbol{\mu g})\end{array}$ & $\begin{array}{c}\text { Resistant } \\
\mathbf{n}(\boldsymbol{\%})\end{array}$ & $\begin{array}{c}\text { Intermediate } \\
\mathbf{n}(\boldsymbol{\%})\end{array}$ & $\begin{array}{c}\text { Susceptible } \\
\mathbf{n}(\boldsymbol{\%})\end{array}$ \\
\hline OFL & 5 & $0(0.00)$ & $0(0.00)$ & $2(100)$ \\
\hline AUG & 30 & $1(50.0)$ & $0(0.00)$ & $1(50.0)$ \\
\hline CAZ & 30 & $2(100)$ & $0(0.00)$ & $0(0.00)$ \\
\hline CRX & 30 & $1(50.0)$ & $1(50.0)$ & $0(0.00)$ \\
\hline GEN & 10 & $0(0.00)$ & $0(0.00)$ & $2(100)$ \\
\hline NIT & 300 & $0(0.00)$ & $0(0.00)$ & $2(100)$ \\
\hline CPR & 5 & $0(0.00)$ & $0(0.00)$ & $2(100)$ \\
\hline CXM & 5 & $1(50.0)$ & $0(0.00)$ & $1(50.0)$ \\
\hline IMP & 30 & $0(0.00)$ & $1(50.0)$ & $1(50.0)$ \\
\hline
\end{tabular}

KEY: (AU) Augmentin, (CAZ) Ceftazidime, (CRX) Cefuroxime, (CTR) Ceftriaxone, (ERY) Erythromycin, (CXC) Cloxacillin, (NIT) Nitrofurantoin (CXM) Cefixime, (OFX) Ofloxacin, (GEN) Gentamycin, (CPX) Ciprofloxacin, (IMP) Imipenem 
Table.7 Antibiotics Sensitivity Pattern of Non-Biofilm Producing Staphylococcus sp Isolated from Bore Hole Water

\begin{tabular}{|c|c|c|c|c|}
\hline Antibiotics & $\begin{array}{c}\text { Concentration } \\
(\boldsymbol{\mu g})\end{array}$ & $\begin{array}{c}\text { Resistant } \\
\mathbf{n}(\boldsymbol{\%})\end{array}$ & Intermediate n(\%) & $\begin{array}{c}\text { Susceptible } \\
\mathbf{n}(\boldsymbol{\%})\end{array}$ \\
\hline OFL & 5 & $0(0.00)$ & $1(50.0)$ & $1(50.0)$ \\
\hline AUG & 30 & $2(100)$ & $0(0.00)$ & $0(0.00)$ \\
\hline CAZ & 30 & $2(100)$ & $0(0.00)$ & $0(0.00)$ \\
\hline CRX & 30 & $0(0.00)$ & $1(50.0)$ & $1(50.0)$ \\
\hline GEN & 10 & $0(0.00)$ & $0(0.00)$ & $2(100)$ \\
\hline CTR & 30 & $0(0.00)$ & $1(50.0)$ & $1(50.0)$ \\
\hline ERY & 5 & $1(50.0)$ & $0(0.00)$ & $1(50.0)$ \\
\hline CXC & 5 & $1(50.0)$ & $0(0.00)$ & $1(50.0)$ \\
\hline IMP & 30 & $0(0.00)$ & $0(0.00)$ & $2(100)$ \\
\hline
\end{tabular}

KEY: (AU) Augmentin, (CAZ) Ceftazidime, (CRX) Cefuroxime, (CTR) Ceftriaxone, (ERY) Erythromycin, (CXC) Cloxacillin, (NIT) Nitrofurantoin (CXM) Cefixime, (OFX) Ofloxacin, (GEN) Gentamycin, (CPX) Ciprofloxacin, (IMP) Imipenem

Table.8 Distribution of biofilm formers and ESBL and MBL producers

\begin{tabular}{|c|c|c|c|c|c|}
\hline Organisms & $\begin{array}{c}\text { Biofilm } \\
\text { formers } \\
\text { No. }(\%)\end{array}$ & $\begin{array}{c}\text { ESBL } \\
\text { Producers } \\
\text { No. (\%) }\end{array}$ & $\begin{array}{c}\text { MBL } \\
\text { Producers } \\
\text { No. }(\%)\end{array}$ & $\begin{array}{c}\text { ESBLand MBL } \\
\text { Producers } \\
\text { No. (\%) }\end{array}$ & $\begin{array}{c}\text { ESBL/MBL and } \\
\text { Biofilm Producers } \\
\text { No. (\%) }\end{array}$ \\
\hline Escherichia coli 4 & $2(50)$ & $1(25)$ & $1(25)$ & $1(25)$ & $1(25)$ \\
\hline Proteus spp 2 & $2(100)$ & $2(100)$ & $1(50)$ & $1(50)$ & $1(50)$ \\
\hline Pseudomonas spp 3 & $3(100)$ & $1(33.3)$ & $2(66.7)$ & $1(33.3)$ & $1(33.3)$ \\
\hline Staphylococcus spp 8 & $6(75)$ & $4(50)$ & $2(25)$ & $2(25)$ & $2(25)$ \\
\hline Total 19 & $13(68.4)$ & $8(42.1)$ & $6(31.6)$ & $5(26)$ & $5(26)$ \\
\hline
\end{tabular}

Key: Extended spectrum beta-lactamase (ESBL), Metalo beta-lactamase (MBL)

Fig 1 Relative Abundance of Biofilm Producing Bacteria Isolated from Bore Hole Water

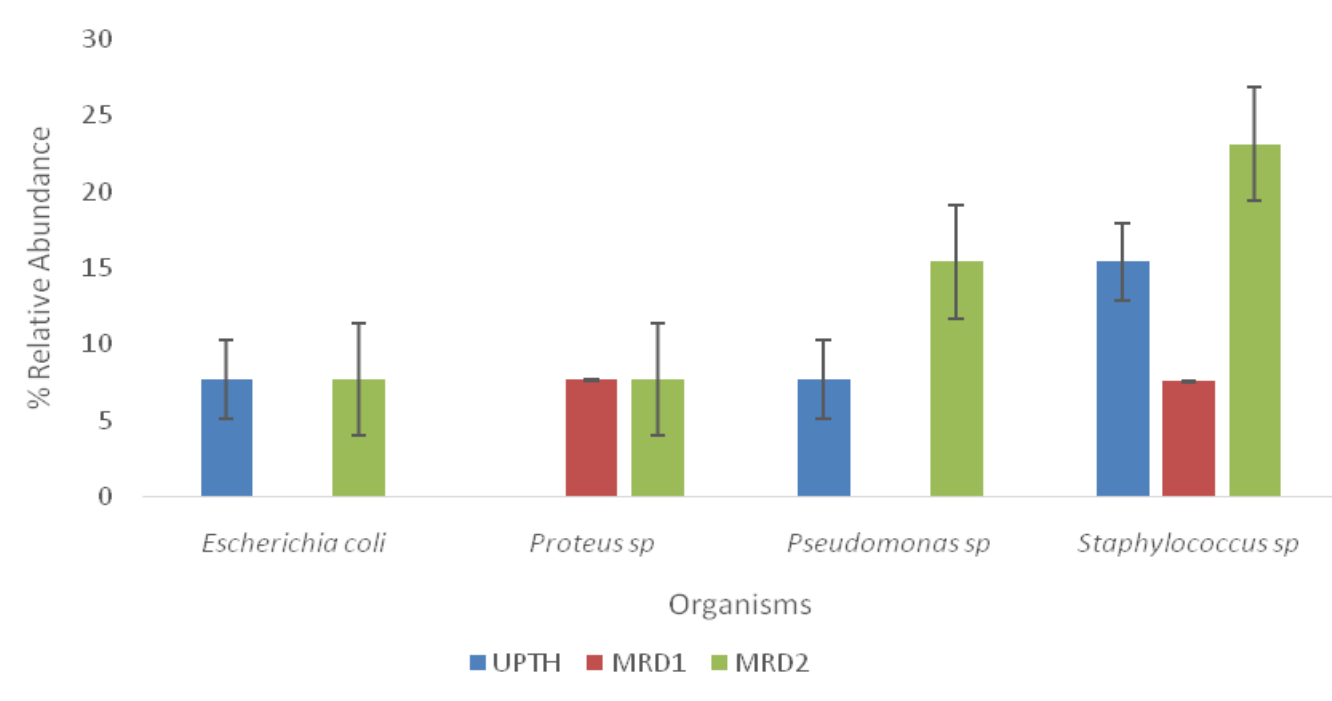


Molecular Identification of Biofilm and Resistant Gene in Biofilm Producing Bacteria

Molecular studies confirmed the identification of Proteus mirabilis and Pseudomonas aeruginosa. The results revealed the gene identification of PapC, CTX-M, ICAD and TET A in the genomic DNA of Pseudomonas aeruginosa, while PapC, CTX-M and ICAD genes were identified in the genomic DNA of Proteus mirabilis. TET A gene variant of the bacteria provides resistance to the antibiotic, Tetracycline. Tetracycline resistance is widespread among gram-positive and gramnegative bacteria and can be the result of drug efflux by bacteria, before reaching its site of action, protecting the ribosomal binding site, which reduces drug binding (49). CTX-M enzymes are a group of class A ESBLs which when present in bacteria, generally confer higher levels of resistance against beta lactam antibiotics such as Cefotaxime, Ceftriaxone and Ceftazidime. Identification of CTX-M gene in the genomic studies of biofilm bacteria is in line with the ESBL phenotypic screening which revealed its presence. A similar result was recorded in (26). Presence of CTX-M of ESBLs is often associated with phenotypes of resistance especially to fluoroquinolones and aminoglycosides. Biofilm polysaccharide intercellular adhesin synthesis protein ICAD gene is an adhesion gene and it was prevalent in the genomic DNA of biofilm producing Proteus mirabilis and Pseudomonas aeruginosa analysed in genomic studies.

The significant increase in biofilm producing bacteria strains and antibiotic resistant bacteria in this study provides a glimpse of the future threat. The study revealed that a higher number of antibiotics were resistant to biofilm producing bacteria as compared with nonbiofilm producers. Physicochemical analysis of water samples from three (3) hospitals showed unsatisfactory properties. Bacteriological analysis of bore hole water revealed that water samples had total heterotrophic bacteria and coliform bacterial counts higher than the World Health Organization satisfactory drinking water limit. Bacteria such as Escherichia coli, Pseudomonas aeruginosa, Proteus, Staphylococcus and Salmonella species were identified in bore hole water from different hospitals and this suggests that waterborne infections may occur among water consumers depending on the level of consumption. Biofilm and non-biofilm bacteria were 100\% resistant to Ceftazidime (third generation cephalosporin).

Ofloxacin, Gentamycin, Imipenem and Nitrofurantoin have been found from this study to be the drug of choice for bacterial biofilm and non-biofilm bacterial infections whose etiological agents are Escherichia coli, Staphylococcus, Proteus, Salmonella and Pseudomonas species. Going by the findings of this study, it becomes necessary that bacterial biofilm counts should be added to the indicators of water quality as they could indicate poor water quality and the presence of virulent bacteria in water. This study also showed that the result revealed from the phenotypic screening of extended spectrum beta lactamases correlates well with the genomic method of extended spectrum beta lactamases gene detection. Thus, this method can be adopted in resource limited settings for the detection of extended spectrum beta lactamases.

\section{Recommendation}

Aseptic conditions should be verified during the repair of pipping materials and treatment of water at source should be frequently encouraged among hospitals studied. Pipping systems should be checked regularly to avoid contamination from broken pipes 
The use of microfiltration filters will aid in water treatment by reducing the level of contaminants in the water, thus eliminating the metallic taste and other undesirable conditions that are expressed by water with contaminants above the maximum acceptable level. Neutralizing filter containing calcite or ground limestone (calcium carbonate) or magnesia (magnesium oxide) can be used to raise the $\mathrm{pH}$ to neutral since water is slightly acidic.

\section{References}

1. Adesoji, A. T. and Ogunjobi, A. A. (2013). Occurrence of Multidrug-Resistant Bacteria in Selected Water Distribution Systems in Oyo State, Nigeria. Global Veterinaria 11(2): 214224

2. Adna, M. A. (2014). Drinking Water Quality Assessment of the Middle East, the Gaza Strip Palestine Water Resources and Industry, (5), 58.

3. Agbabiaka, T. O., Sule, I. O. and Oyeyiola, G. P. (2014). Spatial assessment of public water supplies in densely populated areas of Ilorin Metropolis, Kwara State, Nigeria. Fountain Journal of Natural and Applied Sciences 3(1): 20-28.

4. Amadi, E. S., Ikeagwu, I. J. and Iroha, I. R. (2008). Antibiotic Sensitivity Pattern of Staphylococcus aureus in Abakiliki, Nigeria. Journal Medical Science, 24(2), 231-235

5. Amanidaz, N. (2015). The Intervention Between Heterotrophic Bacteria, Coliform, Faecal Coliform, Faecal Streptococci Bacteria in The Water Supply. Applied and Environmental Microbiology, 12, 53- 60.

6. Azrina, G., Szewzyk, R., Manz, W. and Schleifer, K. H. (2005). Microbiological Safety of Drinking Water. Annual Revised Microbiology, 54, 81-127.

7. Bjarnsholt, T., Kirketerp-Moller, K., Kristiansen, S., Phipps, R., Nielsen, A. K. and Jensen, P. O. (2007). Silver Against Pseudomonas aeruginosa Biofilms. Pathological Microbiology and Immunological Scandinavica, 115: 921-928

8. Buchman, R. E. and Gibbons, N. E. (2004). Bergey's Manual of Determinative Bacteriology. American Journal of Science,
21:529-563

9. Camper, A., Burr, M., Ellis, B., Butterfield, P. and Abernathy, C. (1998). Development and Structure of Drinking Water Biofilms and Techniques for Their Study. Journal of Applied Microbiology. 85: 15-19

10. Chandy, J. and Angles, M. (2001). Determination of nutrients limiting biofilm formation and the subsequent impact on disinfectant decay. Water Resources35(11): 2677-2682

11. Clinical and Laboratory Standard Institute. (2017). Performance Standards for Antimicrobial Susceptibility Testing, Twentyfirst Informational Supplement. 30(1): 68-70.

12. Cook, L. C. and Dunny, G. M. (2014). The Influence of Biofilms in the Biology of Plasmids. Microbiology Spectrum.5(1): 88-82

13. Cowon, E. S. and Steel, K. J. (1993). Identification of Medical Bacteria $3^{\text {rd }}$ Edition, University Press, University Of Cambridge, Edinburgh, Cambridge, United Kingdom. 7884

14. Costerton, J. W., Stewart, P. S. and Greenberg, E. P. (1999). Bacterial Biofilms: A Common Cause of Persistent Infections. Science 284: 1318-1322.

15. Davies, J. and Davies, D. (2010). Origins and Evolution of Antibiotic Resistance. Microbiology and Molecular Biology Reviews.74:417-433

16. Davis, R., Brown, P. D. (2016). Multiple Antibiotic Resistance index, Fitness and Virulence Potential in Respiratory Pseudomonas aeruginosa from Jamaica. Journal of Medical Microbiology. 65: 261 271

17. Donlan, R. M. (2001). Biofilm Formation: A Clinically Relevant Microbiological Process. Clinic Infections and Diseases; 33:1387-92.

18. Emami, S. and Eftekhar, F. (2015). The Correlation Between Bioflm Formation and Drug Resistance in Nosocomial Isolates of Acinetobacter Baumannii. Avicenna Journal Clinical Microbiology Infections; 2:2

19. Eniola, K. I. T., Odaibo, A. D., Olayemi, A. B. and Ajiboye, T. O. (2015). Bacteriological Assessment of Treated Piped Water in Parts of Ilorin Metropolis. Nigerian Journal of Microbiology 28: 2797-2803

20. Fish, K. E., Osborn, A. M., Boxall, J. B. 
(2017). Biofilm Structures (EPS and Bacteria Communities) in Drinking Water Distribution Systems Are Conditioned by Hydraulics and Influence Discolouration. Science of the Total Environment 1: 571-580.

21. Flemming, H-C and Wingender, J. (2010). The biofilm matrix. Nature Reviews Microbiology 8: 623-633.

22. Freeman, J., Falkiner, F. R. and Keane, C. T. (2009). New Method for Detecting Slime Production by Coagulase Negative Staphylococci. Journal Clinical Pathology 42:872-4.

23. Fux, C. A., Costerton, J. W., Stewart, P. S. and Stoodley, P. (2005). Survival Strategies of Biofilm Infectious Biofilms. Trends in Microbiology. 13:34-40

24. Geli, P., Laxminarayan, R., Dunne, M. and Smith, D. L. (2012) "One-Size-Fits-All"? Optimizing Treatment Duration for Bacterial Infections. 7: 298-312.

25. General Laboratory Technology (2007) Percentage Concentration Calculation, Volume Per Volume, Weight Per Volume. Journal of Biological Methods. 6:22-80

26. Ghafourian, S., Sadeghifard, N., Soheili, S., Sekawi, Z. (2015) Extended Spectrum Betalactamases: Definition, Classification and Epidemiology. Current Issues Molecular Biology.17:11-21

27. Hall-Stodley, L., Costerton, J. W., Stoodley, P., (2004). Bacterial Biofilm from the Natural Environment to Infectious Diseases. National Revised Microbial 2(2): 95-108

28. Hanaah, M., Eweida, E. A. and Azza, F. (2000). Heavy Metals in Drinking Water and Their Environmental Impact on Human Health. 3:56-64.

29. Hoiby, N., Bjarnsholt, T., Givskov, M., Molinc, S. and Ciofub, O. (2010). Antibiotic Resistance of Bacterial Biofilms. International Journal of Antimicrobial Agents. 35:322-332

30. Kavcar, P., Sofuoglu, A. and Sofuoglu, S. C. (2009). "A Health Risk Assessment for Exposure to Trace Metals Via Drinking Water Ingestion Pathway," International Journal of Hygiene and Environmental Health, Vol 212, no. 2, pp 216-227.

31. Lewis, K. (2005). Persister Cells and the Riddle of Biofilm Survival. Biochemistry 70: 267-274. 69.
32. Lewis, K. (2001) Riddle of Biofilm Resistance. Antimicrobial Agents Chemotherapy45: 999-1007

33. Mah, T. C. and O'Toole, G. A. (2001). Mechanisms of Biofilm Resistance to Antimicrobial Agents. Trends in Microbiology, 1:34-39.

34. Mathur, T., Singhal, S., Khan, S., Upadhyay, D. J., Fatma, T. and Rattan, A. (2006). Detection of Biofilm Formation among the Clinical Isolates of Staphylococci: An Evaluation of Three Different Screening Methods. Indian Journal Medical Microbiology; 24:25-9

35. Mena, C. B. (2009). Risk Assessment of Pseudomonas aeruginosa in water. Environmental Toxicology, 201:71-115

36. Ndip, R. N., Ebah, L. M. E. and Onile, B. A. (1997). Antibiogram of Staphylococcus aureus Isolated from Clinical Syndromes in Ilorin, Nigeria. Journal of Medical Science.6: 24 26.

37. Nigerian Industrial Standard (2015). Nigerian Standard for Drinking Water Quality.NIS Publication, Abuja, Nigeria, pp 20-21.

38. Niranjan, V. and Malini, A. Antimicrobial Resistance Pattern in Escherichia coli Causing Urinary Tract Infection Among Inpatients. Indian Journal Medical Research.; 6:139-945

39. Okoli, E. C., Chukwu, D. N. O., Idah, N. N., Afiukwa, J. N., Nmezi, P. N. A. and Obeta, A. E (2001). Foundation Chemistry. 1: 2428

40. Oparaocha, E. T., Iroegbu, O. C. and Obi, R. K. (2010). Assessment of Quality of Drinking Water Sources in the Federal University of Technology, Owerri, Imo state, Nigeria. Journal of Applied Bioscience 32: 1964-1976.

41. Ruzicka, F., Hola, V., Votava, M., Tejkalova, R., Horvath, R., Heroldová, M. (2004). Biofilm Detection and The Clinical Significance of Staphylococcus Epidermidis Isolates. Folia Microbiology; 49:596-600.

42. Schwaber, M. J., Navon-Venezia, S., Schwartz, D. (2005). High Levels of Antimicrobial Co-resistance Among Extended Spectrum Beta Lactamase Producing Enterobacteriaceae. Antimicrobial Agents Chemotherapy. 49(5):2137-9

43. September, S. M, Brözel, V. S and Venter, S. 
N. (2004). Diversity of Nontuberculoid Mycobacterium Species in Biofilms of Urban and Semi Urban Drinking Water Distribution Systems. Applied Environmental Microbiology; 70:7571-73.

44. Simoes, L. C., Simoes, M., Oliveira, R. and Vieira, M. J. (2007). Potential of The Adhesion of Bacteria Isolated from Materials. Journal of Basic Microbiology, 47:174-183.

45. Stewardship, W., Series, I. (2007). Iron and Manganese in Groundwater, Br. Columbia Groundwater Association.

46. Strelkova, E. A., Zhurina, M. V., Plakunov, V. K. and Beliaev, S. S. (2012) Antibiotics Stimulation of Biofilm Formation. Mikrobiologiia 81: 282-285.

47. Swarna, S. R., Madhavan, R., Gomathi, S., Devaraj, Thamaraiselvi, S. (2012). A Study of Biofilm on Diabetic Foot Ulcer. International Journal of Pharmaceutical Biological Science. 4:1809-1814

48. Vakulenko, S. B. and Mobashery, S. (2003). Versatility of Aminoglycosides and Prospects for Their Future. Clinical Microbiology Reviews. 16 (3): 430 - 450

49. Wang, W., Guo, Q., Xu, X., Sheng, Z. K., Ye, X., and Wang, M. (2014). High-level Tetracyclin Resistance Mediated by Efflux Pumps. Tet(A) and Tet(A)-1 With Two Start Codons. Journal of Medical Microbiology. 63(11):1454-1459

50. Wasfi, R.., Abd El-Rahman, O. A., Mansour, L. E., Hamora, A S., Hashem, A. M. and Ashpur, M. S. (2021). Antimicrobial Activities Against Biofilm Formed by Proteus Mirabilis
Isolates from Wound and Urinary Tract Infections. Indian Journal Medical Microbiology. 2(2): 54-59

51. Washington, C. W., Stephen, D. A., William, M. J., Elmer, W. K., Gray, W. P. and Paul, C.S.G.L. (2006). Koneman's Colour Atlas and Textbook of Diagnostic Microbiology. 145:234-239

52. W.H.O. (2004). Guidelines for Drinking Water Quality. World Health Organization Geneva, Switzerland, $3^{\text {rd }}$ edition.

53. World Health Organization, WHO. (2008). Guidelines for Drinking-Water Quality In: Recommendations, Volume1, 3rd Edition, World Health Organization Geneva: 3:390 399.

54. World Health Organization, WHO. (2017). Guideline for Drinking Water Quality (Fourth Edition) Incorporating The First Addendum Geneva, Switzerland: WHO Library Cataloguing in Publication ISBN 978-92-4154995-0.

55. Williams, I., Venables, W. A. and Lloyd, D. (1997). The Effects of Adherence to Silicone Surfaces on Antibiotic Susceptibility in Staphylococcus Aureus, Microbiology. 143: 2407-2413.

56. Yong, D., Lee, K., Yum, J. H., Shin, H. B., Rossolini, G. M. and Chong, Y. (2002). Imipenem-EDTA Disk Method for Differentiation of Metallo-B-LactamaseProducing Clinical Isolates of Pseudomonas Spp. and Acinetobacter Spp. Journal of Clinical Microbiology.40(10):3798-3801

\section{How to cite this article:}

Williams, Janet Olufunmilayo, Douglas, Salome Ibietela and Onyedibia, Golden Chukwuma. 2021. Antibiogram and Bacteriological Analysis of Biofilm Producing Isolates in Bore Hole Water from Hospitals facilities in Port Harcourt Rivers State. Int.J.Curr.Microbiol.App.Sci. 10(12): 492-508. doi: https://doi.org/10.20546/ijcmas.2021.1012.055 